\title{
Risk Factor Analysis of Hypertension Occurrence Based on Urban-Rural Location in Indonesia (IFLS Data Study 5)
}

\author{
Bara Bangun Ningharto*, Ayik Mirayanti Mandagi, Rochmad Ardiansyah P, Iswana \\ Zahraa Hidayati \\ ${ }^{1}$ Department of Environmental Health, Public Health Faculty, Airlangga University, Surabaya, Indonesia \\ ${ }^{2,3,4}$ Departmen of Epidemiology, Public Health Faculty, Airlangga University, Surabaya, Indonesia \\ * bara.bangun.ningharto-2015@fkm.unair.ac.id
}

\begin{abstract}
The World Health Organization (WHO) defines hypertension as a "silent killer" disease because the most of hypertension has not signs or symptoms. Nationally, Indonesia in 2016 , the prevalence of hypertension is also higher in urban areas by $31.7 \%$ than in rural areas by $30.2 \%$, the prevalence of hypertension is increasing with the increasing of ages. This study aims to analyze the factors that influence the incidence of hypertension and to determine the most influential factor at risk in the incidence of hypertension based on differences in the location of urban-rural respondents. The research design used in this study was observational analytics based on secondary data from the Indonesia Life Survey 5. The population study is the Indonesian community while the total sample as a whole amounted to 14,824 . Conclusion: factors that influence the incidence of hypertension in urban and rural areas are BMI, age, education, marital status and smoking status.
\end{abstract}

Keywords: Hypertension, Urban, Rural 


\section{STRADA Jurnal Ilmiah Kesehatan}

DOI: $10.30994 /$ sjik.v9i2.258

ISSN: 2252-3847 (print); 2614-350X (online)

Vol.9 No.2 November 2020 Page.494-502

\section{BACKGROUND}

Indonesia in recent times discussed the problem of three burden diseases where the number of infectious diseases is still a problem that is marked by the number of cases of Extraordinary Events (KLB) of some infectious diseases, Indonesia has also overcome the problem by renewing some old infectious diseases (diseases reappear) and appearing new infectious diseases (new-emergig disease). In addition to communicable-related diseases, Indonesia is also burdened with a number of non-communicable diseases which shows an increase in the amount of time that communicable diseases require diabetes, hypertension, stroke, and joint disease. While the risk factors for the incidence of noncommunicable diseases are hypertension, diabetes, high cholesterol.

The World Health Organization (WHO) defines hypertension as a "silent killer" disease because most hypertension has no signs or symptoms. Another thing that causes hypertension is considered a sillent killer is that many people do not know that they have hypertension. The incidence of hypertension according to $\mathrm{WHO}$ is grouped into 2 categories namely prehypertension "at risk" (systolic blood pressure 120-139 mmHg, diastolic 80-89 mmHg), Hypertension "high" (systolic blood pressure> $140 \mathrm{mmHg}$, diastolic $>90 \mathrm{mmHg}$ ).

Globally according to WHO, the prevalence rate of hypertension is $25-35 \%$ almost close to 1 billion people. The incidence of hypertension is 2 out of 3 cases found in developing countries. Hypertension kills at least 8 million people each year worldwide, nearly 1.5 million deaths due to hypertension each year in the Southeast Asian region. Hypertension is also one of the important causes of premature death worldwide and it is estimated that in the year 20251.5 billion adults will be affected by hypertension.

Nationally based on Indonesia's health profile in 2016, the prevalence of the population with high blood pressure was $30.9 \%$ with a higher distribution in women with a prevalence of $32.9 \%$ while in males at $28.7 \%$. The prevalence of hypertension is also higher in urban areas by $31.7 \%$ while in rural areas by $30.2 \%$, the prevalence of hypertension is increasing with age. The increase in the incidence of hypertension is influenced by smoking and exposure to cigarette smoke, unhealthy diet / diet, lack of physical activity, consumption of alcoholic beverages and family history.

This study aims to analyze the factors that influence the incidence of hypertension and look for the factors most at risk for the incidence of hypertension based on differences in the location of urban-rural respondents.

\section{METHODS}

The research design used in this study was observational analytics based on secondary data from Indonesia Life Survey 5 (IFLS5) by RAND Corporation in collaboration with survey meters. IFLS5 survey data collection was conducted from October 2014 to April 2015. The research design carried out in this study was a cross sectional design. In a cross sectional study the researcher made observations without giving special treatment to the variables studied at one time so that it could be used to see the incidence of hypertension and hypertension risk factors (body mass index, physical activity, age, education level, gender, income, marital status, and smoking status) at one time.

The data sampling method in this study is based on the sampling method used in collecting the IFLS5 survey using stratified random sampling techniques grouped by province, and urban-rural location and then samples taken randomly within the strata. 


\section{STRADA Jurnal Ilmiah Kesehatan}

DOI: $10.30994 /$ sjik.v9i2.258

The sampling method carried out resulted in 3 of the 27 provinces in Indonesia representing $83 \%$ of Indonesia's population. Samples welcomed included four provinces in Sumatra (North Sumatra, West Sumatra, South Sumatra and Lampung), five Java provinces (DKI Jakarta, West Java, Central Java, DI Yogyakarta, and East Java), and four provinces that included islands the remaining large islands (Bali, West Nusa Tenggara, South Kalimantan and South Sulawesi). The population in this study is the Indonesian community while the total sample in this study as a whole amounted to 14,824 with a share of 8,951 respondents in urban areas and 5,873 respondents in rural areas.

The analytical method used in this study is simple regression for univariate analysis while for multivariate analysis using logistic regression. The dependent variable in this study was the incidence of hypertension while the Independent variable included body mass index, physical activity, age, education level, gender, income, marital status, and smoking status

\section{RESULT}

Table 1: Univariate Analysis Results

\begin{tabular}{|c|c|c|c|c|c|}
\hline \multicolumn{3}{|c|}{ Urban } & \multicolumn{3}{|c|}{ Rural } \\
\hline Variable & $\begin{array}{l}\text { Frequency } \\
\text { (n) }\end{array}$ & $\begin{array}{c}\text { Percentage } \\
(\%)\end{array}$ & Variable & $\begin{array}{c}\text { Frequency } \\
\text { (n) }\end{array}$ & $\begin{array}{c}\text { Percentage } \\
(\%)\end{array}$ \\
\hline Hypertension & & & Hypertension & & \\
\hline Hypertension & 2,050 & 22.90 & Hypertension & 1,403 & 23.89 \\
\hline Non hypertension & 6,901 & 77.10 & Non hypertension & 4,470 & 76.11 \\
\hline BMI & & & BMI & & \\
\hline Underweight & 839 & 9.37 & Underweight & 681 & 11.60 \\
\hline Normal & 4,956 & 55.37 & Normal & 3,715 & 63.26 \\
\hline Overweight & 3,156 & 35.26 & Overweight & 1,477 & 25,15 \\
\hline Physical Activity & & & Physical Activity & & \\
\hline Low & 1,960 & 21.90 & Low & 913 & 15.55 \\
\hline Is & 3,572 & 39.91 & Is & 2,042 & 34.77 \\
\hline High & 3,419 & 38.20 & High & 2,918 & 49.68 \\
\hline Age (years) & & & Age (years) & & \\
\hline $15-25$ & 1,253 & 14.00 & $15-25$ & 644 & 10,97 \\
\hline $25-34$ & 2,722 & 30.41 & $25-34$ & 1,725 & 29.37 \\
\hline $34-44$ & 2,407 & 26.89 & $34-44$ & 1,485 & 25.29 \\
\hline $45-44$ & 1,551 & 17.33 & $45-44$ & 1,085 & 18.47 \\
\hline $55+$ & 1,018 & 11.37 & $55+$ & 934 & 15.90 \\
\hline Education & & & Education & & \\
\hline Low & 2,599 & 29.04 & Low & 2,954 & 50.30 \\
\hline Is & 4,776 & 53.36 & Is & 2,367 & 40.30 \\
\hline High & 1,576 & 17.61 & High & 552 & 9.40 \\
\hline Gender & & & Gender & & \\
\hline Male & 5,268 & 58.85 & Male & 3,855 & 65.64 \\
\hline Girl & 3,683 & 41,15 & Girl & 2,018 & 34.36 \\
\hline Marital status & & & Marital status & & \\
\hline Marriage & 6,875 & 78.81 & Marriage & 4,853 & 82.63 \\
\hline Not married & 2,076 & 23,18 & Not married & 1,020 & 17.37 \\
\hline Cigarette Status & & & Cigarette Status & & \\
\hline Smoke & 3,536 & 39.50 & Smoke & 2,887 & 49.16 \\
\hline Do not smoke & 5.415 & 60.50 & Do not smoke & 2,986 & 50.84 \\
\hline Total & 8,951 & 100 & & 5,873 & 100 \\
\hline
\end{tabular}




\section{STRADA Jurnal Ilmiah Kesehatan}

DOI: $10.30994 /$ sjik.v9i2.258

ISSN: 2252-3847 (print); 2614-350X (online)

Vol.9 No.2 November 2020 Page.494-502

physical activity, age, education level, gender, income, marital status, and smoking status. The occurrence of hypertension is more common in rural areas with a prevalence of $23.89 \%$ while the incidence of hypertension in urban areas is $22.90 \%$. BMI measurement results obtained dominant normal distribution both in urban and rural areas, the distribution of BMI in urban areas is categorized underweight $(9.37 \%)$, normal $(55.37 \%)$, overwight $(35.26 \%)$ while in rural underweight areas (11.6\%), normal (63\%), and overweight $(25.15 \%)$. The measurement results of physical activity in urban areas are predominant in moderate physical activity (39.91\%) whereas in rural areas it is dominated by respondents with high activity (49.68\%). In the age category, rural and urban areas are more dominant at the age of 25-34 years with a percentage of $30.41 \%$ in urban areas and 29.37 in rural areas. In the education category, urban areas are more dominant in moderate education $(53.36 \%)$ while in rural areas the dominant education is low $(50.30 \%)$. In the gender category, both rural and urban areas were dominated by men with urban areas $(58.85 \%)$ and rural areas $(65.64 \%)$. In the category of marital status both urban and rural dominant in marital status with urban (78.81\%) and rural (82.63\%). In the smoking status category, rural and urban areas are dominated by not smoking with urban distribution $(60.50 \%)$ and rural $(50.84 \%)$.

Table 2: Bivariable Analysis Results

\begin{tabular}{|c|c|c|c|c|c|c|c|c|}
\hline \multirow{3}{*}{$\begin{array}{cc} & \begin{array}{c}\text { Variable } \\
\text { (Hiperten Si })\end{array} \\
\text { BMI } & \end{array}$} & \multicolumn{4}{|c|}{ Urban } & \multicolumn{4}{|c|}{ Rural } \\
\hline & \multirow[t]{2}{*}{ OR } & \multicolumn{2}{|c|}{$95 \% \mathrm{CI}$} & \multirow[t]{2}{*}{$P$-value } & \multirow[t]{2}{*}{ OR } & \multicolumn{2}{|c|}{$95 \%$} & \multirow[t]{2}{*}{$P$-value } \\
\hline & & & & & & & & \\
\hline Normal & 1.86 & 1.47 & 2.36 & 0.00 & 1.57 & 1.25 & 1.97 & 0.00 \\
\hline Overweight & 4.65 & 3.67 & 5.88 & 0.00 & 3.46 & 2.72 & 4.40 & 0.00 \\
\hline \multicolumn{9}{|l|}{ Physical Activity } \\
\hline Is & 1.09 & 0.96 & 1.25 & .19 & 1.13 & 0.95 & 1.36 & .19 \\
\hline High & 1.01 & 0,88 & 1.16 & .86 & 1.05 & 0.88 & 1.25 & 0.59 \\
\hline \multicolumn{9}{|l|}{ Age } \\
\hline $25-34$ & 1.67 & 1.31 & 2.13 & 0.00 & 1.13 & .83 & 1.53 & 0.45 \\
\hline $35-44$ & 3.33 & 2.63 & 4.20 & 0.00 & 2.77 & 3.06 & 3.71 & 0.00 \\
\hline $45-54$ & 7.91 & 6.26 & 10.02 & 0.00 & 5.45 & 4.06 & 7.33 & 0.00 \\
\hline $55+$ & 14.26 & 11.15 & 18.22 & 0.00 & 9.58 & 7.12 & 12.89 & 0.00 \\
\hline \multicolumn{9}{|l|}{ Level P Education } \\
\hline Low & 1.90 & 1.63 & 2.20 & 0.00 & 2.03 & 1.61 & 2.56 & 0.00 \\
\hline Is & 0.87 & 0.75 & 1,00 & 0.05 & 0.88 & 0.69 & 1.12 & 0.32 \\
\hline \multicolumn{9}{|l|}{ Gender } \\
\hline Male & 1.07 & .97 & 1.19 & .18 & 0.88 & .78 & .10 & 0.04 \\
\hline \multicolumn{9}{|l|}{ Marital status } \\
\hline Married & 1.18 & 1.05 & 1.34 & 0.00 & 0.80 & 0.69 & 0,93 & 0.00 \\
\hline \multicolumn{9}{|l|}{ Smoking Status } \\
\hline Smoke & 0.88 & 0.80 & 0.98 & 0.02 & .78 & 0.69 & 0.88 & 0.00 \\
\hline
\end{tabular}

Bivariable analysis is used to determine the factors that influence the incidence of hypertension in Urban-Rural areas in Indonesia. Overweight BMI in urban areas has a 4.65-fold potential to be a factor in hypertension, compared to rural areas which is only 3.46-fold to be a factor in hypertension. Low physical activity is a factor for hypertension, for urban areas it has 1.09 times the potential for hypertension and in rural areas it is 1.13 times the potential for hypertension. The risk factor of age that can trigger hypertension is at the age of 55 years and above, for urban areas it has 14.26 times the potential to experience hypertension compared to rural areas which is only 9.58 times as high as hypertension. Low education level in rural areas has the potential to experience 


\section{STRADA Jurnal Ilmiah Kesehatan}

DOI: $10.30994 /$ sjik.v9i2.258

ISSN: 2252-3847 (print); 2614-350X (online)

Vol.9 No.2 November 2020 Page.494-502

hypertension by 2.03 times compared to low education level in Urban areas which is only 1.90 times as high as hypertension. Male sex in urban areas has 1.07 times the potential for hypertension. Married status in urban areas has 1.18 times the potential to experience hypertension compared to rural areas. The smoking status factor in urban and rural areas is a protective factor for experiencing hypertension. Of the seven factors, the factors that most influence the occurrence of hypertension are those of age. Age 55 years and over has a significant potential to influence hypertension in urban and rural areas.

\section{DISCUSSION}

The relationship between overweight and the incidence of hypertension caused by physiological changes, namely between insulin resistance and hyperinsulinemia; sympathetic nervous system activity and the renin-angiotenin system; and kidney changes. Excessive increase in energy intake can also affect the increase in plasma insulin, which acts as a natriuretic factor and can cause an increase in renal sodium reabsorption so that it can bind to blood pressure (Krummel, 2004).

The results of this study indicate that there is a relationship between BMI overewight with the incidence of hypertension in both Urban and Rural communities. This is in line with research conducted by Fani Rizky et al in 2018 which states that there is a significant relationship between BMI and blood pressure (Fani rizky et al, 2018). Body mass index that exceeds normal or overweight can increase a person's risk of hypertension. The greater the body mass, the more blood is needed to supply oxygen and food to body tissues. This causes the volume of blood circulating through blood vessels to increase, so that it will give greater pressure to the artery walls (Sarah, 2013).

The results of this study also show the results that in urban communities have a risk of 4.65 times affected by hypertension with overweight BMI, while in rural communities who only have a risk of 3.46 times affected by hypertension with overweight BMI. This is not in line with research conducted by Mayla Faroh in 2014 which stated that the incidence of hypertension caused by obesity was higher in rural communities compared to urban communities (Mayla Faroh, 2014). However, this study is in line with the study of Diana, et al (2013) which states that women who live in urban areas are 1.3 times more likely to develop hypertension compared to women who live in rural areas (Diana et al, 2013).

Physical activity increases the use of glucose in muscles and increases insulin sensitivity which causes a decrease in sympathetic nerve activity so that it can reduce systolic and diastolic blood pressure (Lin and Laura, 2012). Theoretically, physical activity influences blood pressure through increasing or decreasing sympathetic nerve activity itself (Mohler and Towsend, 2006)

The results of this study indicate that physical activity increases the risk of hypertension in rural areas. The risk and the percentage of rural communities with physical activity is greater than urban communities. This study is in line with research conducted by Dina AA in 2013 which stated that physical activity of $\leq 600 \mathrm{MET} /$ weeks increased the risk of hypertension in rural areas rather than urban communities (Dina AA, 2013). This is in contrast to research conducted by Moore in 2001, stating that villagers are better protected from hypertension because their lifestyles are more active, such as walking more frequently for daily activities (Moore, 2001).

The impact of urbanization and globalization can trigger rural communities to no longer have a more active lifestyle. Rural communities that visit the city will follow the modern lifestyle of the urban community. Villagers who come to the city can even 


\section{STRADA Jurnal Ilmiah Kesehatan}

DOI: $10.30994 /$ sjik.v9i2.258

ISSN: 2252-3847 (print); 2614-350X (online)

Vol.9 No.2 November 2020 Page.494-502

experience an increase in blood pressure even if they only visit within one month (Ekezie and Anthony, 2011).

Age is a sociodemographic characteristic that is important for the occurrence of hypertension. This is because with increasing age there will be a buildup of collagen and hypertrophy of thin muscle cells that are thin, fragmented and fractured from elastin fibers in blood vessels. This results in structural abnormalities in the form of endothelial dysfunction which increases stiffness in arteries that cannot be avoided. Therefore, elasticity of the arteries is reduced (Black, et al. 2007).

The results of this study indicate that the majority of Indonesian people who experience hypertension, both urban and rural aged 55 years and above. Statistically age is associated with hypertension and the risk of hypertension increases with age. This study is in line with research conducted by Moreira in 2013 in Brazil which shows that the prevalence and risk of hypertension increases with age (Moreira, 2013)

This study is also in line with research conducted by Diana Adlina Amu in 2013 which stated the research showed facts that were not in accordance with the theory that most Indonesian people who experience hypertension, in cities and villages aged 45-54 years. Statistically age is associated with hypertension and the risk of hypertension increases with age (Dina AA, 2013).

The prevalence and risk of hypertension which increases with age increases in urban and rural areas, which means that hypertension can now occur in all age groups and there is no difference between urban and rural areas. Education is the most important thing to increase knowledge. A low level of education regarding hypertension is 2.43 times at risk of developing hypertension (Viera et al, 2008). Good knowledge will generate positive awareness. The community will voluntarily change their lifestyle when they have awareness related to the risk factors of hypertension (Aung et al., 2012: Anggara and Prayitno., 2013).

The results of this study indicate that most urban and rural respondents who suffer from hypertension have low education. The results of this study also indicate that there is a significant relationship between low education levels and hypertension in urban and rural areas. The risk of hypertension in urban and rural areas also increases with the lower level of education of respondents. This is in line with Rahajeng and Tuminah's research in 2009 which stated that the percentage of hypertension was more common among people graduating from elementary / MI (Rahajeng and Tuminah, 2009). The lower the level of public education the higher the risk of experiencing hypertension (Zhang et al, 2013). Although the risk of hypertension in urban and rural areas is increasing along with the low level of public education, the risk of hypertension in urban areas is greater than in rural areas. This is in line with research conducted by Dina Adlina Amu in 2013 that the risk of hypertension is increasing along with the low level of excision, especially in rural areas (Dina AA, 2013).

Women are very susceptible to hypertension due to the role of the hormone estrogen. Estrogen homon plays a role in the protection of resting blood pressure when sympathetic nerve activity results from increased sympathetic nerve muscle activity. In women who are over 40 years old, estrogen production begins to decrease so that protection against blood pressure when there is sympathetic nerve activity will be reduced. Therefore, the prevalence or risk of hepertency will increase in women who have menopause (Robertson, 2012). The results of research conducted by Moreira et al in 2013 indicate that the risk of hypertension in urban and rural areas is higher in women compared to men (Moreira et al, 


\section{STRADA Jurnal Ilmiah Kesehatan}

DOI: $10.30994 /$ sjik.v9i2.258

ISSN: 2252-3847 (print); 2614-350X (online)

Vol.9 No.2 November 2020 Page.494-502

2013). Research conducted by Prabhakaran et al prevalence of hypertension is higher in women than men in urban areas (Prabhakaran et al, 2007). In addition, research in rural Liaoning China showed 1,293 women had hypertension compared to men (Xu et al, 2008).

However, the results of this study indicate a different matter. The percentage of hypertension is higher in men than women, both in urban and rural areas. In addition, there is no relationship between sex and hypertension in rural areas. Whereas in urban areas, gender is a potential factor for hypertension. Several studies have shown that the prevalence or risk of hypertension is higher in men compared to women. As a study conducted by Dina AA in 2013 said that the percentage of hypertension was higher in men compared to women, both urban and rural areas (Dina AA, 2013).

The results of this study indicate that marital status is significantly related to hypertension factors both in urban and rural areas. This study is in line with research conducted by Lelly Andayasari and Cicih Opitasari in 2015, based on marital status that more than 50\% of hypertensive patients are married (Lelly Andayasari and Cicih Opitasari, 2015). Another study states that hypertension in married women has a prevalence of $40.73 \%$ (Elmi Nuryati, 2012)

Smoking habit plays a role in the cause of hypertension, because cigarettes contain nicotine and carbon monoxide which affect blood pressure. Nicotine can increase fatty acids, activate platelets, trigger aterosklrerosis and constriction of blood (Cahyono, 2008; MOH RI, 2006). Meanwhile, carbon monoxide causes damaged hemoglobin in the blood so that it accumulates in the capillary membrane and can cause thickening of the walls of blood vessels (Schnitzer, 2000; MOH RI, 2006). The results of this study indicate that smoking status is a protective factor for hypertension in urban and rural areas. But regarding the relationship of smoking status with the incidence of hypertension in urban and rural areas has a significant relationship.

This is in line with research conducted by Aggraini, et al in 2009, stating that there is a significant relationship between smoking habits and the incidence of hypertension (Anggraini, 2009). This study is also in line with research conducted by Sartik et al in 2017 which states that there is a statistically significant relationship between smoking and the incidence of hypertension.

\section{CONCLUSION}

The proportion of respondents with hypertension is more in rural areas compared to the proportion of hypertension in urban areas. The factors that influence the incidence of hypertension in urban and rural areas are BMI, age, education, marital status and smoking status. The age factor of 55+ is the most influential factor in the incidence of hypertension in both urban and rural areas. Therefore, prevention and control of hypertension are very important to reduce the prevalence and risk of hypertension in the urban and rural areas of Indonesia.

\section{REFERENCES}

Andayasari, Lelly dan Cicih Opitasari., 2015, Determinan Hipertensi di Puskesmas dan RSUD Kabupaten Natuna, Jurnal Biotek Medisiana Indonesia, Vol 4.2.2015 Hal 89-98

Anggara F. H. D. dan Prayitno N. 2013. Faktor-faktor yang Berhubungan dengan Tekanan Darah di Puskesmas Telaga Murni, Cikarang Barat Tahun 2012. Jurnal Ilmiah Kesehatan, 5 (1): jan 2013. 


\section{STRADA Jurnal Ilmiah Kesehatan}

DOI: $10.30994 /$ sjik.v9i2.258

ISSN: 2252-3847 (print); 2614-350X (online)

Vol.9 No.2 November 2020 Page.494-502

Anggraini, dkk. 2009. Faktor-faktor yang Berhubungan dengan Kejadian Hipertensi pada Pasien yang Berobat di Poliklinik Dewasa Puskesmas Bangkinang Periode Januari sampai Juni 2008. Makalah. Universitas Negeri Riau

Amu,. Dina Adlina. 2013. Faktor-Faktor yang Berhubungan dengan Hipertensi di wilayah perkotaan dan Pedesaan Indonesia tahun 2013. Skripsi. [Online] http://repository.uinjkt.ac.id/dspace/bitstream/123456789/28885/1/DINA\%20ADLI NA\%20AMU-FKIK.pdf

Black, H.R dan Elliot, W.J. 2007. Hypertension: A Companion to Braunwald's Heart Disease. USA:Elsevier.

Boreham C, Twisk J, van Mechelen W, Savage M, Strain J, Cran G. Relationships between the development of biological risk factors for coronary heart disease and lifestyle parameters during adolescence: the Northern Ireland Young Hearts Project. Public Health 1999;113(1):7-12.

Departemen Kesehatan Republik Indonesia (Depkes RI). 2006. Pedoman Teknis Penemuan dan Tatalaksana Hipertensi.

Ekezie, J., dkk. Impact o urbanization on Obesity, Anthropometric Profile and Blood Pressure in the Igbos of Nigeria. North American Journal of Medical Sciences 2011 May; 3(5); 242-246

Krummel. 2004, Medical Nutrition Therapy in Hypertension. Didalam Mahan LK dan Escott-Stump S, Editro. 2004 Food. Nutrition and Diet Therapy. USA: Saunders co. Hlm. 900-918

Lin P. H. dan Laura. 2012. Nutrition, Lifestyle Factors and Blood Pressure. United State: Taylor \& Francis Group

Mohler, . R. dan Townsend, R.R. 2006. Advanced Therapy in Hypertension and Vascular Dusease. Ontario: BC Decker

Moreira J.P., Moraes, J.R. dan Luiz, R.R. 2013. Prevalence of Selft-Reported Systemic Arterial Hypertension In Urban and Rural Environments in brazil: A Populationbased Study. Cad Saude Publica, Rio de Janeiro, 29 (1): 62-72

Moore, R. D. 2001. The High Blood Pressure Solution : A Scientifically Proven Program for Preventing Strokes and Heart Disease. Vermont: Healing Arts

Nabila, Mayla Faroh. 2014. Perbedaan Kejadian Hipertensi pada Masyarakat Rural-Urban di Kabupaten Bogor Tahun 2014. [Skripsi].

Nuryati, Elmi., 2012. Studi Prevalensi Hipertensi pada Wanita Menikah di Provinsi Lampung, Jurnal Ilmiah Kesehatan, vol 1:hal 11

Nugraheni, Fani Rizky, dkk., 2018. Hubungan Asupan Mineral, Indeks Massa Tubuh dan Persentase Lemak Tubuh terhadap Tekanan Darah Wanita Subur (Studi di Wilayah Kerja Puskesmas Ngemplak Simongan Semarang). Semarang: JKM e-Journal.

Prabhakaran, D., dkk. 2007. Difference in The Prevalence of Metabolic Syndrome in Urban and Riral India: A Problem of Urbanization. Sage Pub. Chronic Ilness 2007 3:8

Robetson, D. et al. 2012. Primer on the Autonomic Nervous System. Third Edition. USA: Elsevier

Sartik., dkk. 2017. Faktor-faktor Risiko dan Angka Kejadian Hipertensi pada penduduk Palembang. Palembang: Jurnal Ilmu Kesehatan Masyarakat

Viera, A. J. 2008. High Blood Pressure Knowledge among Primary Care Patients with Known Hypertension: A North Carolina Family Medicine Research Network (NCFM-RN) Study. (Journal Am. Board Fam. Med. 2008;21:300-308) 


\section{STRADA Jurnal Ilmiah Kesehatan}

DOI: $10.30994 /$ sjik.v9i2.258

ISSN: 2252-3847 (print); 2614-350X (online)

Vol.9 No.2 November 2020 Page.494-502

Xu, C. dkk. 2008. Prevalence of and Risk Factors for Isolated Systolyc Hypertention in the Rural Adult Population of Liaoning Province, China. Journal of International Medical Research 36:353 